\title{
DO PREDATORS HAVE RIGHTS?
}

\author{
by ROBERT W. PAGE*
}

Of all the species on earth, man, the edator, is the most successful. He $\mathrm{n}$ be found almost anywhere and he timately has dominion over the other eatures with which he shares this anet. Man has domesticated some rds and mammals and has then atmpted to ruthlessly eliminate the maining animals that compete with $m$ in any way. His main competitors ve, of course, been other predators; is with them that early man came to conflict when seeking food hongst the earth's grazing and owsing animals. Today, with his eat herds of cattle, sheep, pigs and rses man still maintains his ruthless mpetitive attitude towards fellow edators.

In Canada this competition has led relentless pressure being applied to ch animals as wolves, cougars, grizbears, coyotes and foxes. Birds too ve been subjected to man's selfish fusal to co-exist. Hawks, eagles and Is have provided instant target actice whenever their paths crossed at of a man with a gun. In the past, mers and hunters have either been porant of or downgraded the useful le that predators play and they have $t$ considered the ethical question of ether such species have a right to ist or not. Such thinking has been plied to the new technology ailable to gunners and the result has en spectacles such as the Kenora If hunts of Ontario, the now inmous Quebec acrylic jaw-bone phy wolf hunts and Saskatchewan's owmobile fox and coyote hunts. The

0 Ash Street,

nnipeg. Manitoba. latter are carried out legally with the sanction of the Saskatchewan Department of Natural Resources. The changing attitudes of an increasingly better educated, more civilized electorate across Canada has brought an end to the Ontario and Quebec wolf hunts but in Saskatchewan there is still debate as to whether or not foxes and coyotes should be hunted from power toboggans or other motorized vehicles. While the majority of people now feel that the Canadian experience is one of both civilization and wilderness and that respect must be shown for all members of the natural world, others mount their snowmobiles and roar off to destroy whatever foxes or coyotes they can exhaust, shoot or run down. Actually, running down the animal is illegal, but there is usually nobody around to see that an animal, tortured to the point of exhaustion, is shot instead of having its back broken by a snow machine.

In the past, few people really cared if something like this went on, but as the relative size of our planet shrinks and as humans become more plentiful and wildlife more scarce, people are beginning to feel that perhaps animals do have a right to exist. If specific animals become a real problem, and by real I mean a problem documented by government wildlife or agricultural personnel through field checks, then it may be necessary to kill those individuals but even then they have a right to a humane death.

If a particular area in Saskatchewan is suffering excessive predation on livestock or game, then some controls should be initiated. However, the loss of a sickly calf to a coyote should not 
be considered a predator problem. Ranchers know that no coyote can take a healthy calf from a cow that is still interested in its welfare. Similarly, it is questionable whether or not one can reasonably call it a predator problem if lambs are left unattended in an enclosure without a dog or adequate fencing or some other kind of protection. Sloppy farming practices can sometimes attract predators into an area. If we are going to live with a balanced view of nature, some onus should be on the farmer to ward off possible problems. Killing predators should be the last, not the first, line of attack.

In the past, when a predator problem arose, overreaction was usually the rule, not the exception. The widespread dropping of poison baits was one solution. This caused the indiscriminate, cruel and long-suffering death of any predator that ate the poison bait. It did the same to all other birds and mammals that ate either the baits or their poisoned victims. The rights of animals to a humane death hardly entered the minds of the public or their wildlife departments. Oth control methods have included le hold traps, hunting from aircraft ar now from snowmobiles. The: methods were effective, often to effective, but they gave no col sideration to the animals being col trolled. In effect, control appeared be an attempt at widespread, is discriminate elimination.

More positive solutions to predat problems exist but their acceptan requires a better appreciation of th role of predators in our environmen Their value as rodent controlle should be made more widely know should their effectiveness in taking th weak, old and sick individuals of gam species. Man and hunter seek prim animals, but predators that kill to li scek out the least healthy as a sur way to fill their stomachs. The valu the enjoyment that people can obta from living in a province with multiplicity of animals should also publicized, as well as the fact th man's assumed enemy, the predato has many traits in common with hir For too long we have identified wi

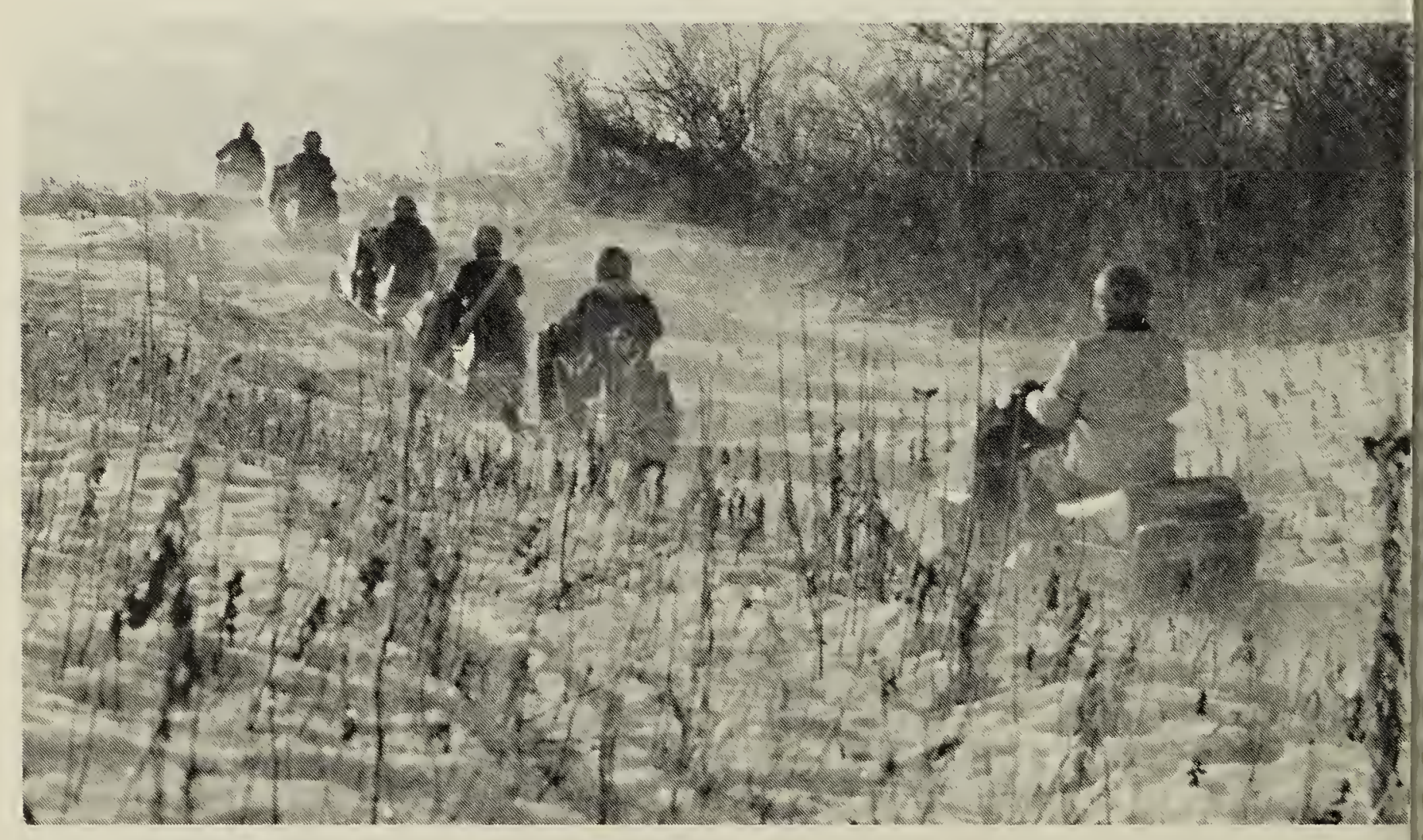

Snowmobiles

Sask. Photo/Arts Servici 
and birds of our earth, rather than a brash, ruthless dictatorial approach whereby everything - animal and plant - that appears in his way must be destroyed.

Finally, there is the actual problem of controlling snowmobile abuses. With more snowmobilers getting their recreation from running down foxes and coyotes, how does one get them to stop there? As long as our society accepts the use of snowmobiles to hunt one or two species, it will be more ready to overlook the hunting of other animals, anything from jack rabbits to deer and moose. As long as one kind of snowmobile hunting is legal, it is less likely that the courts will be sufficiently severe on other illegal forms of motorized hunting.

It would be appropriate if members

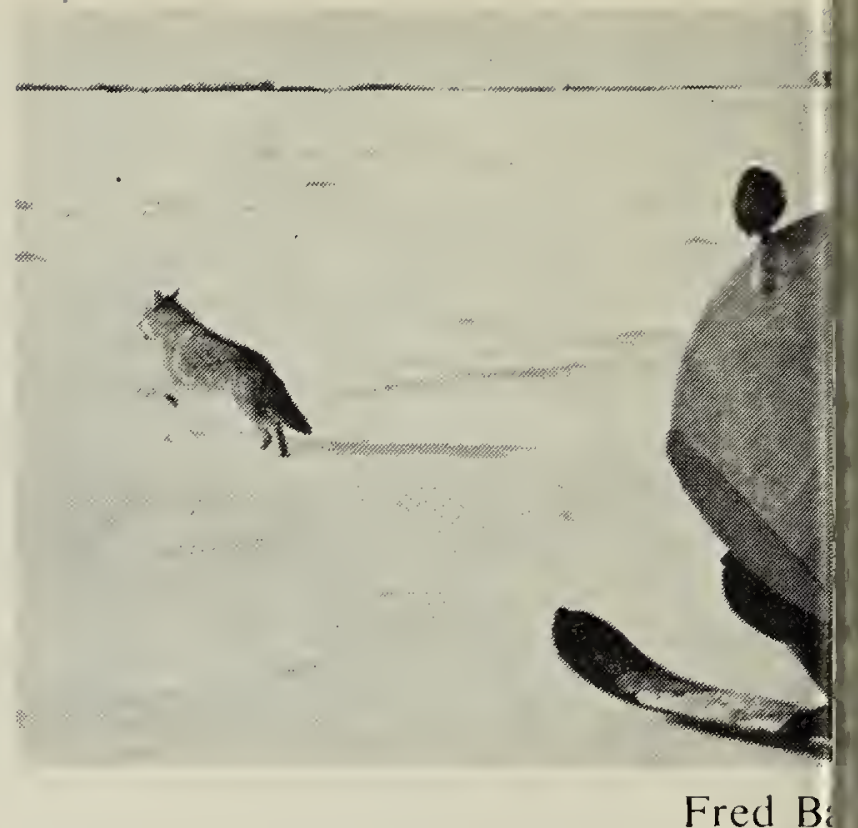

Coyote being chased by snowmobile.

of the Saskatchewan Natural Hist Society and other readers of the $B$ Jay would write to Saskatchewan's n resource minister, the Honourat John Kowalchuk, care of the $A$

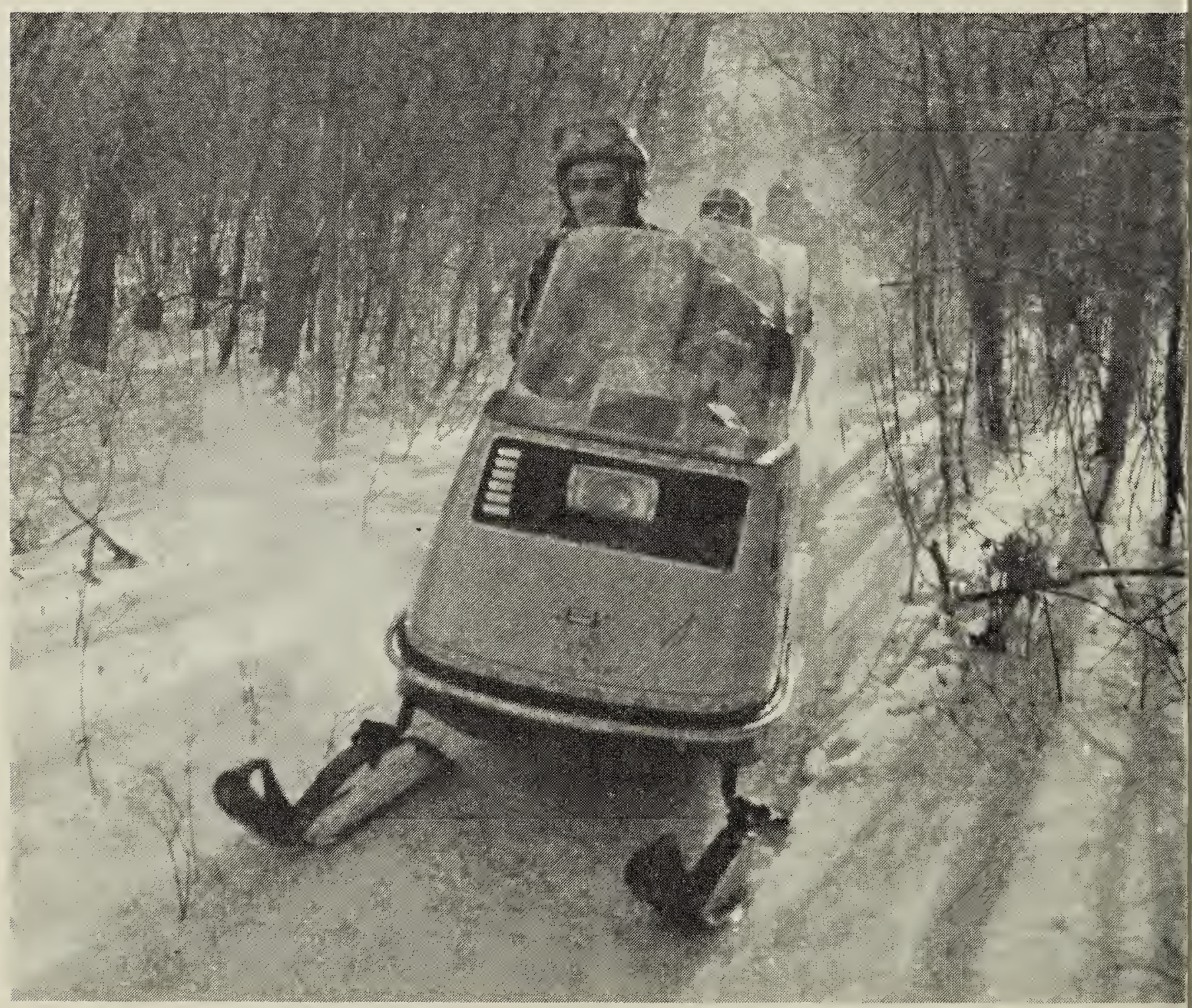

Snowmobiles in woods

Sask. Photo/Arts Servi 
inistration Building, Regina, and exess their views on legislation that lows municipalities to issue permits people to use snowmobiles to hunt edators.

Hopefully, 1974 will be the last year is practice is allowed. Saskatchewan, ith its strong Natural History Society, beautiful Natural History Museum Regina and its rich diversity of ildlife and scenery is presently emished by its winter snowmobile ints. This is not something about hich a thoughtful citizen can be oud.

\section{ABSTRACT FROM SASK. D.N.R. POLICY CONCERNING PREDATOR PERMITS}

(Oct. 2, 1972)

OM INTENT: "The practice of pursuing d killing wild animals with power boggans has resulted in ... the 1970 ssion of the legislature (amending) Secon 29 of the Game Act (to read as llows:)

Unless expressly authorized by the minister, no person shall use a power boat or vehicle for the purpose of: (a) chasing or pursuing any wild animal or wild bird; (b) disturbing any wild animal or wild bird; (c) driving any wild animal or wild bird towards hunters; or (d) injuring or killing any wild animal or wild bird with such power boat or vehicle.

"Unfortunately, in certain agricultural areas in Saskatchewan, rural residents are confronted with local problems of predation by coyote and/or fox which are difficult to handle by conventional methods of control... Therefore, it is deemed necessary to issue permits to rural residents so affected to deal with these local problems. There is no intention whatsoever to permit the use of motor toboggans for sport hunting or pelt hunting."

From POLICY: "1. Special permits to use snow toboggans for hunting fox and coyote will be issued when these animals are calusing depredation problems. The permits are to be issued by the Conservation Officer...

"2. Local Conservation Officers must be prepared to discuss the conditions of issuing such permits with the local R.M. council. The importance of restricting authorization for permits to bonafide cases of animals causing predation should be stressed.

"3. The R.M. or L.I.D. will only be required to pass one resolution authorizing the Department to issue permits to residents within the R.M. or L.I.D.

From APPLICATION: "List total losses of livestock or poultry during the past three months caused by coyotes or fox and dates (applicant's land only)

\title{
COUGARS IN MANITOBA
}

\author{
by ROBERT W. NERO*
}

In the early years, cougars were erhaps uncommon in Manitoba but

Fondensed from Conservation Comment, ablished monthly and available free from anitoba Dept. of Mines, Resources and Enronmental Management, Box 11, 139 Tuxedo vd., Winnipeg, Manitoba. R3C OV 8 with the increase in White-tailed Deer populations, cougars seem to have increased in number. Since the 1960's, especially, there have been several wel! documented sightings of cougars. For the 71-year period from 1879 to 1950 there are only 16 reports of cougars in the province, but 21 reports 